\title{
ANALISIS FAKTOR-FAKTOR YANG MEMPENGARUHI PROFITABILITAS DAN IMPLIKASINYA PADA CORPORATE VALUE
}

\author{
Aria Aji Priyanto* \\ Program Studi Manajemen, Universitas Pamulang \\ *email : dosen01048@unpam.ac.id
}

DiPublikasi: 01/01/2020

http://dx.doi.org/10.22225/kr.11.2.1154.190-196

\begin{abstract}
This research objective to explore the factors that impact the firm's profitability viz. firm size, liquidity, and leverage and so determine its implications for Corporate Value. Corporate value is measured calculating with the Tobins $Q$ Index. This type of research is comparative causal with a quantitative approach. The population of this research is the sub sector of Transportation company listed on the Indonesia Stock Exchange during 2010-2017 with the final sample determination of 7 companies. Data analysis method is using path analysis and the sobel test technique. Factors that affect profitability viz. firm size, liquidity, and leverage are only evidenced through liquidity which has a negative effect on profitability while profitability has a positive effect on corporate value. Firm size and leverage have no significant effect on profitability. Finally, Firm Size, Liquidity, and Leverage in this research weren't able to evaluate Corporate Value through profitability which functioned as an intervening variable Keywords: Profitability, Liquidity, Corporate Value

Abstrak

Penelitian ini bertujuan untuk menganalisis faktor-faktor yang mempengaruhi Profitabilitas Perusahaan yang terdiri dari Ukuran Perusahaan, Likuiditas dan Leverage untuk mengetahui implikasinya terhadap Corporate Value. Corporate value diukur menggunakan perhitungan Indeks Tobins Q. Jenis penelitian ini menggunakan kausal komparatif dengan pendekatan kuantitatif. Populasi penelitian ini adalah perusahaan Sub Sektor Transportasi yang terdaftar di Bursa Efek Indonesia selama tahun 2010-2017 dengan penetapan sampel akhir 7 perusahaan. Metode analisis data dilakukan dengan analisis jalur dan menggunakan teknik sobel test. Faktor-faktor yang mempengaruhi Profitabilitas yang terdiri dari Ukuran Perusahaan, Likuiditas dan Leverage hanya dibuktikan melalui likuiditas berpengaruh negatif terhadap profitabilitas perusahaan sedangkan profitabilitas berpengaruh positif terhadap corporave value. Ukuran Perusahaan dan leverage tidak berpengaruh signifikan terhadap profitabilitas perusahaan. Akhirnya, faktor Ukuran Perusahaan, Likuiditas, dan Leverage pada penelitian ini tidak mampu mengevaluasi Corporate Value melalui Profitabilitas yang difungsikan sebagai variabel intervening.
\end{abstract}

Kata Kunci : Profitabilitas, Likuiditas, Corporate Value

\section{PENDAHULUAN}

Pemegang saham adalah pihak yang memegang kekuasaan tertinggi dalam Perseroan. Nilai perusahaan dapat diukur dengan kehandalan informasi yang dimuat pada laporan kinerja perusahaan yang dijadikan dasar dalam pembuatan keputusan investasi, manajemen aset dan sumber pendanaan (Elinda \& Sukirman, 2015). Setiap perusahaan memiliki berbagai faktor dalam menentukan tujuan perusahaan berdasarkan kategori industri yang sama. Faktor-faktor ini disebut dengan karakteristik perusahaan (Restanti \& Husain, 2018). Karakteristik perusahaan diklasifikasikan melalui 3 (tiga) pendekatan, yaitu struktur, kinerja dan pangsa pasar. Pendekatan struktur meliputi skala perusahaan berdasarkan kepemilikan aset (ukuran perusahaan), kapabilitas dalam melunasi kewajiban-kewajiban perusahaan (leverage) dan hubungan antara tingkat pengembalian tahunan atau pendapatan. Pendekatan kinerja (perfomance) perusahaan meliputi likuiditas perusahaan dan laba yang terkait dengan profitabilitas dan penjualan. Pendekatan pangsa pasar mencakup komponen jenis industri, status perusahaan dan spesifikasi auditor. Keseluruhan karakteristik tersebut dituangkan dalam rasio-rasio keuangan perusahaan (Haryanto \& Aprilia, 2008). Analisis faktor rasio-rasio ini sangat bergantung pada kemampuan analis laporan 
keuangan dalam mengaplikasikan dan menginterpretasikannya karakteristik informasiinformasi yang terdapat di dalam maupun luar perusahaan.

Faktor-faktor perusahaan yang biasa dilihat awalnya oleh investor yaitu besar kecilnya skala perusahaan atau disebut dengan ukuran perusahaan. Ukuran perusahaan adalah suatu konstruk yang sering dikaji dalam studi-studi bidang manajemen, akuntansi dan perpajakan. Berdasarkan Pernyataan Standar Akuntansi Keuangan (PSAK) Nomor 16, Paragraf 06, aset didefinisikan menjadi aset berwujud yang dimiliki untuk digunakan dalam penyediaan barang atau jasa serta proses produksi, atau, disewakan kepada pihak lainnya, serta dalam tujuan yang sifatnya administratif dengan harapan dapat digunakan lebih dari satu periode (IAI, 2013). Banyak penelitian yang menggunakan pengukuran total aset untuk mengukur besar kecilnya suatu perusahaan.

Faktor penting lainnya yaitu likuiditas, likuiditas memiliki efek terbalik dengan profitabilitas, dimana penurunan profitabilitas terkait langsung dengan peningkatan likuiditas karena terdapat aset produktif yang berlebih dan tidak dimanfaatkan sehingga diperlukan adanya optimalisasi kebijakan manajemen modal kerja agar aset tetap likuid dan tidak berdampak ke dalam laba bersihnya (Horne \& Wachowicz Jr., 2012). Faktor pendanaan yang berasal dari utang juga memiliki efek terbalik dengan profitabilitas, dimana semakin meningkatnya rasio ini berarti perusahaan memiliki potensi kinerja yang kurang baik. Semakin tinggi utang yang dimiliki dibandingkan dengan kepemilikan yang bersumber dari modal pemegang saham maka semakin besar dampak yang dihadapi investor akan risiko keuangan sehingga investor cenderung mengambil keputusan kepada manajemen untuk meningkatkan profitabilitas perusahaan sebesar-besarnya. Utang yang tinggi memiliki dampak adanya beban rutin (fixed expense) yang harus diterima perusahaan yang berdampak dengan menurunnya laba yang diperoleh dan nilai perusahaan di mata investor (Azmy \& Vitriyani, 2019). Penentuan nilai perusahaan (corporate value) akan selalu menjadi

\section{TINJAUAN PUSTAKA}

Rasio keuangan merupakan faktor penting dalam mengukur laba bersih dan kinerja perusahaan, rasio ini menjadi tools yang populer dan paling banyak digunakan untuk menganalisis informasi keuanoan dan meruiuk kenada domain utama bagi kalangan akademisi dan praktisi yang menarik untuk dianalisis, dikaji ulang dan diteliti dengan melibatkan seperangkat faktorfaktor tertentu.

Industri sektor transportasi menjadi perhatian Pemerintah Indonesia seiring dengan percepatan pembangunan infrastruktur dalam negeri kurun waktu 10 tahun terakhir. Menurut Laporan Bappenas (Bab 33), langkah-langkah kebijakan dan hasil yang dicapai berfokus pada prasarana jalan, lalu lintas angkutan jalan, perkeretaapian, angkutan sungai dan penyebrangan, transportasi laut dan udara, dan penunjang sektor transportasi (Kementerian PPN/ Bappenas, hal. 33.18-33). Menjelang MEA 2016, para operator transportasi agar secara manajerial ikut menyuksesi dalam menyongsong diberlakukannya pasar tunggal ASEAN tahun 2016 akan berdampak pada liberalisasi sektor ini sehingga operator transportasi beroperasi pada negara-negara anggota ASEAN melalui asas cabotage moda transportasi laut dan udara yang akan berdampak ke perekonomian nasional khususnya saham-saham jasa transportasi (Kementerian Perhubungan Republik Indonesia, 2015). Realisasi atas bisnis sektor ini sangat membantu dalam memberikan pelayanan pada keseharian masyarakat dengan produk-produk seperti penjualan tiket kereta api, pemesanan kamar hotel, penjualan tiket penerbangan, transaksi jualbeli, ojek online, taksi dan moda transportasi lainnya yang menggunakan basis teknologi atau aplikasi, hal ini tentunya menjadi solusi bagi para pengguna atas jasa yang disediakan oleh pelaku bisnis untuk menghadapi persoalan masyarakat tersebut (Widhiasthini \& Subawa, 2019).

Penelitian ini menggunakan objek penelitian pada perusahaan sub sektor Transportasi yang listing di Bursa Efek Indonesia (BEI) tahun 2010-2017. Perbedaan penelitian ini dengan penelitian terdahulu yaitu hanya berfokus faktor karakteristik perusahaan yaitu ukuran perusahaan, serta faktor rasio keuangan yaitu likuiditas dan leverage untuk mengevaluasi tingkat Profitabilitas dan implikasinya terhadap Corporate Value.

keterkaitan antar entitas ekonomi (Subramanyam, 2014, hal. 33). Total aset merupakan determinan utama untuk menjadi penyebut dalam beberapa rasio keuangan yang digunakan. Total aset mengoambarkan ukuran nerusahaan herdasarkan Page 191 
keseluruhan aset perusahaan pada posisi periode tertentu. Ukuran ini diklasifikasi menjadi aset lancar dan aset tidak lancar (current dan noncurrent assets). Current asset terbagi menjadi 5 (lima) bagian, yaitu: (1) kas dan equivalent; (2) investasi dalam jangka pendek (short-term investment); (3) piutang (receivable); (4) persediaan (inventory) dan beban dibayar dimuka (prepaid expenses) sementara non-current assets terdiri dari: (1) investasi jangka panjang (long term invesment); (2) aset tetap (fixed assets yaitu property, plant and equipment); (3) aset tidak berwujud (intangible assets) dan aset lain-lain (other assets) (Kieso, Weygandt, \& Kimmel, 2013). Pengukuran atas total aset dalam mengidentifikasi besar kecilnya skala perusahaan dapat dilakukan dengan menjumlahkan aset lancar dan aset tidak lancar dalam laporan posisi keuangan (neraca) perusahaan.

Likuiditas adalah pemenuhan kewajiban keuangan perusahaan yang segera harus dipenuhi, atau kemampuan perusahaan dalam melunasi kewajiban keuangan ketika suatu waktu ditagih (Kasmir, 2016). Menurut Keown (2011), likuditas dapat diukur dengan beberapa pendekatan: (1) rasio lancar (current ratio) yaitu dengan mengkomparasi kas dan aset-aset yang dapat dikonversi ke dalam kas perusahaan pada tahun dengan membayar atas kewajiban yang jatuh tempo pada tahun berjalan (Subramanyam, 2014, hal. 546); dan (2) rasio cepat (acid-test ratio) yang menggunakan aset lancar dengan mengeluarkan unsur persediaan, dimana menjadi bagian yang paling tidak likuid dalam numerator (Subramanyam, 2014, hal. 599).

Leverage adalah pemenuhan pembiayaan perusahaan atas utang, atau mengukur sejauhmana aset perusahaan dapat dibiayai oleh keberadaan utang (Kasmir, 2016). Rasio ini berfungsi untuk mengidentifikasi bagian atas setiap kepemilikan ekuitas perusahaan yang dijaminkan atau keseluruhan utang perusahaan untuk menilai jumlahnya yang akan dieksekusi. Perusahaanperusahaan yang profitable cenderung akan menyimpan laba (retained earnings) untuk investasi atau retensi yang berpotensi akan memprioritaskan pengembangan equity dibandingkan dengan debt. Perusahaan pada umumnya menggunakan baik pendanaan utang maupun melalui ekuitas. Leverage perusahaan dapat didefinisikan sebagai besarnya pendanaan utang dalam struktur kepemilikan perusahaan dalam bentuk modal (Subramanyam, 2014:565).

Berbagai cara untuk menoukur profitabilitas, lebih baik menggunakan Return On Assets (selanjutnya disebut dengan ROA). ROA dapat diartikan dengan perbandingan faktor margin laba atas perputaran kepemilikan aset, jika salah satu faktor yaitu marjin laba atau kepemilikan aset meningkat, maka berdampak pada meningkatnya nilai ROA. Semakin tinggi nilai ROA yang menunjukkan perusahaan memiliki kinerja yang semakin baik. Investor akan menaruh kepercayaan kepada pihak manajemen bahwa manajemen akan mengelola aset secara efektif untuk mencapai laba yang optimal bagi shareholders' (Rudianto, 2015). ROA adalah pengukuran atas kemampuan perusahaan dalam menghasilkan keuntungan dengan seluruh aset yang dimilikinya. Kondisi rentabilitas perusahaan yang baik mendorong setiap investor untuk mengeksekusi portofolio investasi, investor akan sangat berkepentingan untuk berinvestasi dalam jangka waktu yang panjang. Keuntungan usaha yang dihasilkan oleh nasabah dengan return kepada investor dengan perhitungan berupa feedback rate tidak hanya berdasarkan pendapatan atau penjualan (Yanti, 2018). Pengukuran tingkat profitabilitas dengan komponen ROA mencerminkan efisiensi aktivitas operasional perusahaan dalam mencapai target keuntungannya melalui laba bersih (Titman, Keown, \& Martin, 2018, hal. 88).

Nilai perusahaan didefinisikan dengan istilah: "corporate value which is the present value of expected free cash flow, discounted at a weighted average cost of capital" (Brigham \& Houston, 2014, hal. 58). Nilai sekarang dapat diuraikan sebagai nilai sekarang atas arus kas bebas pada masa mendatang dengan tingkat diskonto dengan rata-rata tertimbang atas biaya modal. Rasio Tobin's Q menjadi alternatif yang digunakan dalam mengukur nilai perusahaan (Heder \& Priyadi, 2017). Rasio ini oleh James Tobin dikembangkan dan dapat memberikan informasi yang bernilai atas fenomena dalam aktivitas perusahaan, misalnya pada keterkaitan kepemilikan saham pihak manajemen dengan kinerja perusahaan dalam suatu nilai tertentu. Nilai perusahaan dapat diukur menggunakan pendekatan analisis rasio berdasarkan nilai pasar (market value) yang mencakup price earnings ratio (PER), market book ratio (MBR), price book value ratio (PBVR), dan dividend payout ratio (DPR). Pengukuran rasio Tobins' $Q$ dihitung atas kondisi perusahaan untuk jangka waktu yang lama sebagai bentuk kepercayaan publik atas perusahaan (Elim, 2019). Penentuan nilai nerusahaan selalu meniadi_domain Jurnal KRISNA: Kumpulan Riset Akuntansi Volume 12, Nomor 22021 CC-BY-SA 4.0 License 
utama bagi kalangan akademisi dan praktisi yang menarik untuk dianalisis dengan melibatkan beberapa faktor seperti skala perusahaan dalam ukuran tertentu, likuiditas dan leverage perusahaan serta faktor profitabilitas yang menjadi anteseden untuk melihat kinerja keuangan perusahaan.

Penelitian ini dilatarbelakangi oleh beberapa hasil penelitian antara lain: (1) Penelitian tahun 2015 yang menggunakan sampel perusahaan Farmasi periode 2009-2012 sebanyak 9 perusahaan, dengan temuan riset yang menguji struktur modal menghasilkan pengaruh yang tidak signifikan dari faktor ukuran perusahaan dan risiko bisnis sementara pengaruh yang signifikan atas faktor likuiditas dengan arah positif dan pengaruh yang signifikan atas faktor profitabilitas dengan arah yang positif (Dwija Bhawa \& Dewi S., 2015). (2) Pada tahun 2017 menggunakan 37 data observasi non-partisipan yaitu publikasi Bursa Efek Indonesia melalui ICMD atas perusahaan manufaktur tahun 2011-2015, dengan temuan riset bahwa ukuran perusahaan dan leverage berpengaruh signifikan dengan arah positif sementara profitabilitas berpengaruh tidak signifikan dengan arah negatif masing-masing terhadap nilai perusahaan. Corporate Social Responsibility (CSR) yang difungsikan sebagai pemoderasi mampu membuktikan pengaruh atas profitabilitas, leverage tetapi tidak berfungsi sebagai pemoderasi pengaruh atas ukuran perusahaan terhadap nilai perusahaan (Wulandari \& Wiksuana, 2017). (3) Pada tahun 2017 dengan 13 sampel pada sektor industri konsumsi yang terdaftar di BEI periode 2012-2015, temuan riset hasil kinerja keuangan berpengaruh terhadap nilai perusahaan dengan arah positif dan kepemilikan manajerial berfungsi sebagai pemoderasi antara kinerja keuangan dengan nilai perusahaan (Heder \& Priyadi, 2017). (4) Penelitian tahun 2017 dengan melibatkan 30 perusahaan Sub Sektor Telekomunikasi sampel selama 2011-2016 atas pengaruh Likuiditas, Pertumbuhan Penjualan, dan
Risiko Bisnis terhadap Nilai Perusahaan, dimana likuiditas dan pertumbuhan penjualan berpengaruh signifikan terhadap nilai perusahaan dengan arah positif serta risiko bisnis berpengaruh signifikan terhadap nilai perusahaan dengan arah negatif (Trisna Dewi \& Sujana, 2019). (5) Faktor-faktor yang mempengaruhi Return On Assets yang melibatkan subjek penelitian $P T$. Indocement Tunggal Prakarsa Tbk. selama tahun 2007-2017 dengan hasil yang membuktikan atas pengaruh perputaran tunai dan perputaran piutang secara parsial memiliki signifikansi terhadap nilai ROA (Priyanto, 2019). (6) Pengaruh Rasio Kinerja Keuangan Terhadap Nilai Perusahaan BUMN NonKeuangan Di Bursa Efek Indonesia dari periode Januari 2012 hingga Desember 2016 dengan temuan hasil bahwa ROA dan EPS berpengaruh signifikan terhadap nilai perusahaan sementara DER dan PER tidak berpengaruh signifikan (Azmy \& Vitriyani, 2019). (7) Prediksi firm's value berdasarkan Profitabilitas dan Kebijakan Dividen pada 11 perusahaan sub-sektor Otomotif dan Komponen yang listing di BEI selama tahun 20142018 dengan pengukuran price-to book value (PBV). Temuan penelitian ini gagal memprediksi dampak firm's value atas profitabilitas melalui kebijakan dividen (Husain, Sarwani, Sunardi, \& Lisdawati, 2020).

Rumusan masalah dapat dijawab melalui suatu kerangka berpikir yang membentuk sintesa yang mencerminkan keterkaitan antara variabel yang diteliti dan merupakan tuntunan untuk memecahkan masalah penelitian serta merumuskan hipotesis penelitian yang dilengkapi penjelasan kualitatif (Sugiyono, 2018). Kerangka berpikir tersebut diturunkan ke dalam suatu model penelitian untuk membatasi ruang lingkup penelitian. Model penelitian adalah konstruk dalam turunan bentuk, struktur, isi serta jumlah dan makna yang dipisahkan oleh suatu boundary dengan parameter yang spesifik (Husain T. , 2019). 


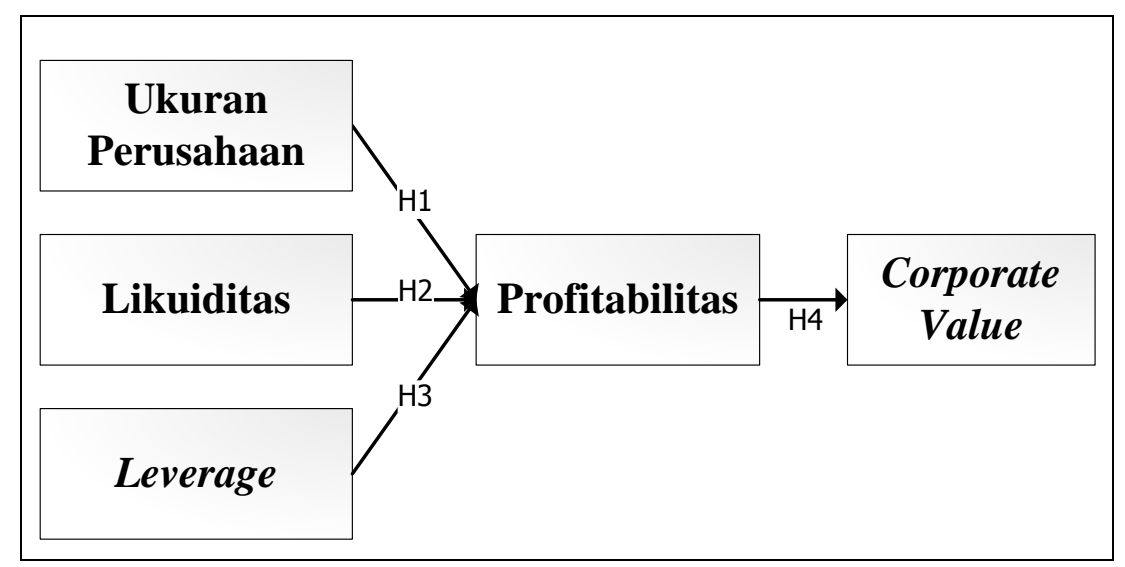

Gambar 1. Model Penelitian

Model penelitian ini dinyatakan ke dalam hipotesis alternatif (Ha) sebagai berikut:

\section{Pengaruh Ukuran Perusahaan Terhadap Profitabilitas}

Ukuran perusahaan merupakan teknik dalam mengidentifikasi besar kecilnya skala perusahaan yang umumnya menggunakan total aset (kepemilikan aset perusahaan). Kepemilikan ini tertuang dalam laporan posisi keuangan yaitu penjumlahan antara aset lancar dengan aset tidak lancar. Penelitian Dwija Bhawa dan Dewi S. di tahun 2015 tidak membuktikan adanya pengaruh ukuran perusahaan terhadap struktur modal perusahaan sementara penelitian Wulandari dan Wiksuana di tahun 2016 membuktikan pengaruh positif atas ukuran perusahaan dalam memprediksi nilai perusahaan. Gap penelitian di atas melatarbelakangi untuk menguji kembali hipotesis alternatif pertama yang dinyatakan:

$\mathrm{H}_{1}$ : Ukuran Perusahaan berpengaruh positif terhadap Profitabilitas

\section{Pengaruh Likuiditas Terhadap Profitabilitas}

Likuiditas merupakan kemampuan perusahaan dalam melunasi kewajiban keuangan ketika suatu waktu ditagih yang berasal dari aset lancarnya. Penelitian Dwija Bhawa dan Dewi S. di tahun 2015 membuktikan adanya pengaruh positif likuiditas terhadap struktur modal perusahaan sementara penelitian Trisna Dewi dan Sujana di tahun 2019 membuktikan pengaruh likuiditas terhadap nilai perusahaan dengan arah yang positif dan penelitian Priyanto yang juga di tahun 2019 membuktikan pengaruh negatif atas perputaran kas dan pengaruh positif atas perputaran piutang dalam mengidentifikasi likuiditas terhadap profitabilitas. Gap penelitian di atas melatarbelakangi untuk menguji kembali hipotesis alternatif kedua yang dinyatakan:
$\mathrm{H}_{2}$ : Likuiditas berpengaruh negatif terhadap Profitabilitas

Pengaruh Leverage Terhadap Profitabilitas

Leverage merupakan pemenuhan pembiayaan perusahaan yang bersumber dari utang, atau mengukur sejauhmana aset perusahaan dapat dibiayai oleh keberadaan utang. Penelitian Wulandari dan Wiksuana di tahun 2017 membuktikan adanya pengaruh positif leverage terhadap nilai perusahaan sementara penelitian Azmy dan Vitriyani di tahun 2019 tidak membuktikan pengaruh leverage terhadap nilai perusahaan. Gap penelitian di atas melatarbelakangi untuk menguji kembali hipotesis alternatif ketiga yang dinyatakan:

$\mathrm{H}_{3}$ :Leverage berpengaruh negatif terhadap Profitabilitas

\section{Pengaruh Profitabilitas Terhadap Corporate Value}

Profitabilitas merupakan pengukuran atas kemampuan perusahaan dalam menghasilkan keuntungan dengan seluruh aset yang dimilikinya. Penelitian Dwija Bhawa dan Dewi S. di tahun 2015 membuktikan adanya pengaruh positif profitabilitas dalam mengukur struktur modal perusahaan sementara penelitian Heder dan Priyadi di tahun 2017 dan Azmy dan Vitriyani di tahun 2019 membuktikan pengaruh kinerja keuangan terhadap nilai perusahaan. Penelitian Husain, et al. di tahun 2020 gagal membuktikan profitabilitas terhadap firm's value. Gap penelitian di atas melatarbelakangi untuk menguji kembali hipotesis alternatif keempat yang dinyatakan:

$\mathrm{H}_{4}$ :Profitabilitas berpengaruh positif terhadap Corporate Value

Pengaruh Ukuran Perusahaan, Likuiditas dan Leverage Terhadap Corporate Value melalui Profitahilitas 
Hasil Penelitian Wulandari dan Wiksuana di tahun 2017 hanya membuktikan pengaruh profitabilitas dan leverage yang dimediasi oleh Corporate Social Responsibility (CSR) terhadap nilai perusahaan dengan proksi Rasio Tobin's Q sementara pada penelitian Husain, et al. di tahun 2020 faktor profitabilitas gagal dimediasi oleh dividend policy dalam memprediksi nilai perusahaan dengan proksi PBV. Gap penelitian di atas melatarbelakangi

\section{METODE PENELITIAN}

Tempat, Obyek Penelitian, Populasi dan Metode Penentuan Sampel

Penelitian ini dilaksanakan di Bursa Efek Indonesia (BEI). Objek Penelitian adalah Laporan Keuangan Tahunan, perusahaan sub sektor Transportasi yang terdaftar di BEI. Metode pengumpulan data menggunakan dokumentasi, dengan men-download daftar perusahaan serta laporan keuangan perusahaan di portal BEI (www.idx.co.id).

Metode penentuan sampel menggunakan nonprobability sampling dengan teknik purposive sampling dimana sampel dipilih atas kriteriakriteria tertentu. Adapun kriteria-kriteria pengambilan sampel dalam penelitian ini:

1 Perusahaan sub sektor Transportasi yang terdaftar di BEI dan mempublikasikan laporan keuangan auditan per 31 Desember secara konsisten dan lengkap sejak 2010-2017 dan tidak mengalami delisting dari BEI selama periode pengamatan.

2 Laporan keuangan yang menggunakan mata uang pelaporan dalam satuan mata uang asing dikonversikan ke Kurs Tengah BI (IDR)

\section{Data dan Sumber Data}

Penelitian ini menggunakan data sekunder, yaitu data yang dinyatakan dalam bentuk angka-angka atau data yang berbentuk kualitatif yang diangkakan (Sugiyono, 2018, hal. 12). Data tersebut adalah laporan keuangan tahunan yang diterbitkan oleh perusahaan sub sektor Transportasi yang terdaftar di BEI periode 2010-2017 yang juga berasal dari website resmi masing-masing perusahaan yang dijadikan sampel.

Definisi Operasional Variabel dan Pengukurannya

Variabel dependen dalam penelitian ini adalah Rasio Tobin's Q (Z). Rasio ini menunjukkan untuk merumuskan hipotesis alternatif kelima hingga ketujuh yang memfungsikan Profitabilitas sebagai variabel intervening yang dinyatakan:

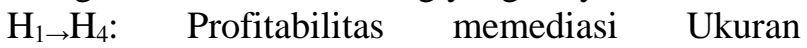
Perusahaan terhadap Corporate Value $\left(\mathrm{H}_{5}\right)$

$\mathrm{H}_{2 \rightarrow} \mathrm{H}_{4}$ : Profitabilitas memediasi Likuiditas terhadap Corporate Value $\left(\mathrm{H}_{6}\right)$

$\mathrm{H}_{3} \rightarrow \mathrm{H}_{4}$ : Profitabilitas memediasi Leverage terhadap Corporate Value $\left(\mathrm{H}_{7}\right)$

gambaran bentuk kepercayaan publik atas perusahaan dengan suatu nilai tertentu. Variabel Independen dalam penelitian ini adalah Ukuran Perusahaan (X1) dengan proksi log_total assets, Likuiditas (X2) dengan proksi Current Ratio (CR) dan Leverage (X3) dengan proksi Debt-to Equity Ratio (DER). Variabel intervening dalam penelitian ini adalah Profitabilitas (Y) dengan proksi Return On Assets (ROA).

\section{Metode Analisis Data}

Penelitian ini menggunakan metode analisis data yaitu Analisis Jalur (path analysis) dengan bantuan aplikasi stastistik SPSS for Windows Ver23.00 dan Sobel test. Tahapan analisis data yaitu: (1) analisis statistik deskriptif; (2) uji asumsi klasik meliputi uji normalitas data, uji multikolinearitas, uji heteroskedastisitas dan uji autokorelasi; (3) uji linieritas menggunakan pendekatan curve-fit; (4) uji hipotesis dengan direct effect melalui persamaan regresi berganda; dan (5) uji hipotesis indirect effect dengan Sobel test. Persamaan regresi dirumuskan sebagai berikut:

$\mathrm{Y}=+1 \mathrm{X} 1+2 \mathrm{X} 2+3 \mathrm{X} 3+\mathrm{e} 1$

(1)

$Z=+4 X 1+5 X 2+6 X 3+7 Y+e 2$

(2)

Keterangan:

\begin{tabular}{|c|c|}
\hline $\mathrm{X} 1-\mathrm{X} 3$ & Variabel Independen \\
\hline Y & Variabel Intervening \\
\hline Z & Variabel Dependen \\
\hline$\alpha$ & Konstansa \\
\hline$\beta_{1} \ldots \beta_{7}$ & $\begin{array}{l}\text { Koefisien Regresi } \\
\text { Frror }\end{array}$ \\
\hline
\end{tabular}

terdaftar di Bursa Efek Indonesia dengan periode pengamatan selama 2010-2017. Setelah

\section{HASIL DAN PEMBAHASAN}

Populasi penelitian adalah 38 (tiga puluh delapan) perusahaan Sub Sektor Transportasi yang 
mempertimbangkan kriteria penilaian sampel, perusahaan dengan hasil pertimbangan seleksi penelitian ini hanya menggunakan 7 (tujuh)

sampel berikut ini:

Tabel 1. Hasil Seleksi Sampel

\begin{tabular}{ccc}
\hline Kriteria Sampel & $\begin{array}{c}\text { Pelanggaran } \\
\text { Kriteria }\end{array}$ & Jumlah Perusahaan \\
\hline $\begin{array}{c}\text { Perusahaan Sub Sektor Transportasi } \\
\text { Perusahaan yang delisting atau relisiting pada } \\
\text { tahun penelitian yaitu 2010-2017 }\end{array}$ & - & 37 \\
$\begin{array}{c}\text { Perusahaan yang menggunakan pelaporan } \\
\text { tanggal tutup buku perusahaan selain 31 } \\
\text { Desember (RIGS) } \\
\text { Data Ekstrim }\end{array}$ & $(1)$ & 15 \\
& & \\
\hline
\end{tabular}

(Sumber: Data diolah, 2020)

Data observasi yang dilakukan selama tahun 2010-2017 yaitu 56 (lima puluh enam) pengamatan. Adapun kode emiten, nama dan

tanggal initial public offerings (IPO) perusahaan pada Sub Sektor Transportasi yaitu:

Tabel 2. Daftar Nama Perusahaan Sampel

\begin{tabular}{cccc}
\hline No. & $\begin{array}{c}\text { Kode } \\
\text { Emiten }\end{array}$ & Nama Perusahaan & Tanggal IPO \\
\hline 1 & BLTA & PT Berlian Laju Tanker, Tbk. & 26-Mar-1990 \\
2 & CMPP & PT Air Asia Indonesia, Tbk. & 08-Des-1994 \\
3 & IATA & PT Indonesia Air Transport \& Infrastruktur, & 13-Sept-2006 \\
& & Tbk. & 17-Mei-2001 \\
4 & INDX & PT Tanah Laut, Tbk. & $15-$ Agust- \\
5 & SAFE & PT Steady Save, Tbk. & 1994 \\
& & PT Samudera Indonesia, Tbk. & 05-Des-1999 \\
6 & SMDR & PT Weha Transportasi Indonesia, Tbk. & 03-Mei-2007 \\
\hline
\end{tabular}

(Sumber: Data diolah, 2020)

Hasil Statistik Deskriptif

Hasil statistik deskriptif pada variabel penelitian ini dipetakan berdasarkan sebaran nilai sampel, nilai minimum dan maksimum serta nilai rata-rata dengan simpangan bakunya.

Tabel 3. Hasil Analisis Statistik Deskriptif Descriptive Statistics

\begin{tabular}{lccccc}
\hline & $\mathrm{N}$ & Minimum & Maximum & Mean & Std. Deviation \\
\hline Ukuran Perusahaan & 56 & 9,958600 & 13,409000 & 11,64778214 &, 917182841 \\
Likuiditas & 56 &, 0164 & 6,0000 &, 972798 & 1,0635112 \\
Leverage & 56 & $-2,4400$ & 5,0900 &, 963541 & 1,4948079 \\
Profitabilitas & 56 &,- 1679 & 2,1921 &, 082636 &, 3376628 \\
Corporate Value & 56 &, 2457 & 13,6937 & 2,557679 & 3,0316161 \\
Valid N (listwise) & 56 & & & & \\
\hline
\end{tabular}

(Sumber: Output SPSS Ver23.00, 2020)

1. Ukuran Perusahaan (X1) menghasilkan sebaran data yang berkisar antara skor minimum hingga maksimum dengan logaritma 9,958600 dan 13,409000. Nilai rata-rata diperoleh sebesar logaritma 11,64778214 dengan standar deviasi sebesar
0,917182841. Artinya, 56 data observasi pada perusahaan sub sektor transportasi yang terdaftar di BEI selama tahun 2010-2017 menghasilkan variasi data sampel yang sangat kecil (perbandingan nilai rata-rata dengan standar deviasi kurang dari $30 \%$ ). 
2. Likuiditas (X2) menghasilkan sebaran data yang berkisar antara skor minimum hingga maksimum dengan current ratio 0,0164 kali dan 6 kali. Nilai rata-rata diperoleh sebesar 0,972798 kali dengan standar deviasi sebesar 1,0635112. Artinya, 56 data observasi pada perusahaan sub sektor transportasi yang terdaftar di BEI selama tahun 2010-2017 menghasilkan variasi data sampel yang relatif besar (perbandingan nilai rata-rata dengan standar deviasi mendekati skor 1).

3. Leverage (X2) menghasilkan sebaran data yang berkisar antara skor minimum hingga maksimum dengan nilai minus $-2,44$ kali dan 5,09 kali. Nilai rata-rata diperoleh sebesar 0,963541 kali dengan standar deviasi sebesar 1,14948079. Artinya, 56 data observasi pada perusahaan sub sektor transportasi yang terdaftar di BEI selama tahun 2010-2017 menghasilkan variasi data sampel yang yang relatif besar (perbandingan nilai rata-rata dengan standar deviasi mendekati skor 1).

\section{Uji Asumsi Klasik}

Hasil uji normalitas dilakukan dengan

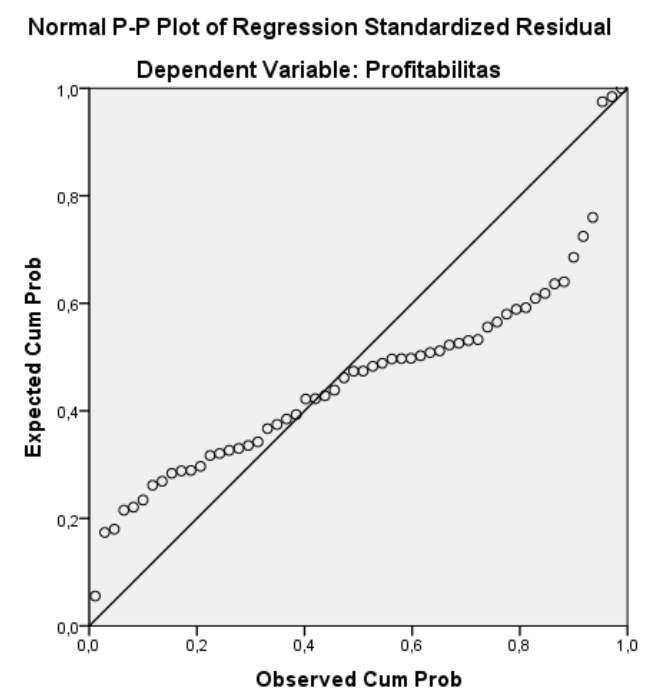

(Sumber: Output SPSS Ver23.00, 2020)

\section{Gambar 2. Grafik P-Plot Hasil Uji Normalitas}

Grafik P-Plot yang menunjukkan bahwa sebaran unstandardized residual berada di sekitar garis diagonal dan mengikuti arah garis diagonal sehingga nilai residu dari model persamaan regresi
4. Profitabilitas (X4) menghasilkan sebaran data yang berkisar antara skor minimum hingga maksimum dengan return-on assets minus $-0,1679$ dan 2,1921. Nilai rata-rata diperoleh sebesar 0,082636 dengan standar deviasi sebesar 0,33376628. Artinya, 56 data observasi pada perusahaan sub sektor transportasi yang terdaftar di BEI selama tahun 2010-2017 menghasilkan variasi data sampel yang sangat kecil (perbandingan nilai rata-rata dengan standar deviasi kurang dari $30 \%)$.

5. Corporate Value $(\mathrm{Z})$ menghasilkan sebaran data yang berkisar antara skor minimum hingga maksimum dengan indeks 0,2457 dan 13,6937. Nilai rata-rata diperoleh sebesar 2,557679 dengan standar deviasi sebesar 3,0316161. Artinya, 56 data observasi pada perusahaan sub sektor transportasi yang terdaftar di BEI selama tahun 2010-2017 menghasilkan variasi data sampel yang cukup besar (perbandingan nilai rata-rata dengan standar deviasi lebih dari 30\%).

melihat sebaran unstandardized residual melalui 2 (dua) persamaan regresi yaitu:

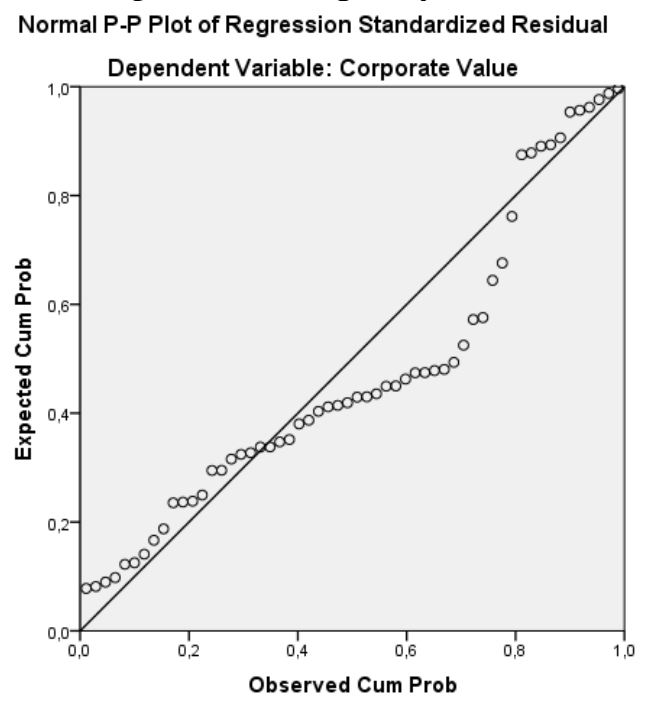

1 dan 2 terdistribusi secara normal atau telah memenuhi normalitas data. Uji Heteroskedastisitas dilakukan dengan melihat grafik scatterplot melalui 2 (dua) persamaan regresi yaitu: 

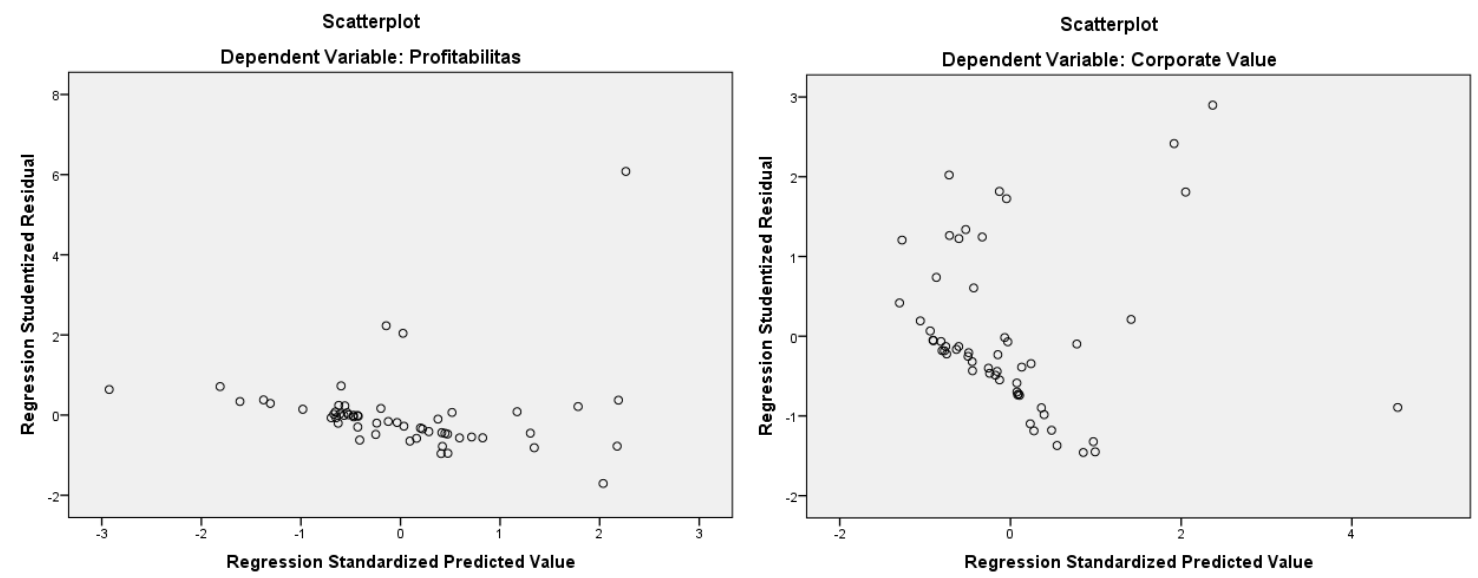

(Sumber: Output SPSS Ver23.00, 2020)

Gambar 3. Scatter Diagram Hasil Uji Heteroskedastisitas

Grafik scatterplot masing-masing variabel heteroskedastisitas. Uji Multikolinearitas dilakukan Profitabilitas (Y) dan Corporate Value (Z) dengan melihat skor tolerance dan VIF (varian menghasilkan titik-titik menyebar di atas dan di inflated factors) melalui 2 (dua) persamaan regresi bawah angka 0 dan sumbu Y, yang berarti bahwa yaitu: model regresi ini telah terbebas dari masalah

Tabel 4. Rangkuman Hasil Uji Multikolinearitas

\begin{tabular}{lcccc}
\hline \multirow{2}{*}{$\begin{array}{c}\text { Variabel } \\
\text { Penelitian }\end{array}$} & \multicolumn{2}{c}{ Model Regresi 1 } & \multicolumn{2}{c}{ Model Regresi 2 } \\
\cline { 2 - 5 } & $\begin{array}{c}\text { Skor } \\
\text { Tolerance }\end{array}$ & $\begin{array}{c}\text { Skor } \\
\text { VIF }\end{array}$ & $\begin{array}{c}\text { Skor } \\
\text { Tolerance }\end{array}$ & $\begin{array}{c}\text { Skor } \\
\text { VIF }\end{array}$ \\
\hline Ukuran Perusahaan & 0,869 & 1,151 & 0,860 & 1,162 \\
Likuiditas & 0,881 & 1,135 & 0,760 & 1,281 \\
Leverage & 0,776 & 1,289 & 0,734 & 1,362 \\
Profitabilitas & - & - & 0,854 & 1,171 \\
\hline
\end{tabular}

(Sumber: Data diolah, 2020)

Hasil uji multikolinearitas pada masing-masing model regresi menghasilkan skor tolerance lebih dari 0,1 dan VIF kurang dari 10, yang berarti bahwa kedua model regresi ini terbebas dari permasalahan multikolinearitas antar variabel independen. Uji autokorelasi dilakukan dengan melihat skor durbin watson (dw) yang dibandingkan dengan nilai $\mathrm{dU}$ dan $\mathrm{dL}$ pada $\mathrm{k}=3$ (model regresi 1) dan $\mathrm{k}=4$ (model regresi 2 ) pada $\mathrm{n}=56$.

Tabel 5. Rangkuman Hasil Uji Autokorelasi

\begin{tabular}{rcccc}
\hline Variabel Penelitian & \multicolumn{2}{c}{ Regresi 1 } & \multicolumn{2}{c}{ Regresi 2 } \\
\cline { 2 - 5 } & Skor dL & Skor dU & Skor dL & Skor dU \\
\hline Model & 1,4581 & 1,6830 & 1,402 & 1,7246 \\
Durbin Watson $(\mathrm{dw})$ & \multicolumn{2}{c}{2,072} & \multicolumn{2}{c}{2,880} \\
\hline
\end{tabular}

(Sumber: Data diolah, 2020)

Hasil uji autokorelasi pada model regresi 1 dan 2 menghasilkan skor dw sebesar lebih besar dari skor dU yaitu 2,072 dan 2,880 (berada di antara du

\section{Uji Linieritas}

Hasil uji linieritas dilakukan dengan melakukan pemenuhan asumsi dalam model path analysis agar menghasilkan spesifikasi model yang dengan 4-dU) yang berarti tidak ada autokorelasi baik positif maupun negatif.

tepat. Pengujian ini mgnggunakan pendekatan curve fit - parsimony of concepts yaitu bilamana seluruh model yang diuji apakah signifikan atau tidak signifikan, berfungsi linier signifikan artinya 
model dapat dikatakan linier. Spesifikasi model yang digunakan sebagai dasar pengujian menggunakan satuan linier, kuadratik, kubik, inverse, logarithmic, power, S, compound, growth dan eksponensial.

Tabel 6. Rangkuman Hasil Uji Linieritas (Curve Fit)

\begin{tabular}{lccccccc}
\hline $\begin{array}{l}\text { Model } \\
\text { Regresi }\end{array}$ & $\begin{array}{c}\text { Spesifikasi } \\
\text { Model }\end{array}$ & $\begin{array}{c}\text { Nilai } \\
\mathbf{R}^{\mathbf{2}}\end{array}$ & $\begin{array}{c}\text { Nilai } \\
\mathbf{F}\end{array}$ & $\mathbf{d f 1}$ & $\mathbf{d f 2}$ & Sig. & Hasil Pengujian \\
\hline & & & & & & 0,00 & \\
& & & & & & 0 & \\
& & & & & & 0,00 & \\
$\mathrm{X} 1 \rightarrow \mathrm{Y}$ & Luadratic & & & & & \\
$\mathrm{X} 2 \rightarrow \mathrm{Y}$ & $\mathrm{S}$ & 0,208 & 14,172 & 1 & 54 & 0,44 & Signifikan \\
$\mathrm{X} 3 \rightarrow \mathrm{Y}$ & Quadratic & 0,030 & 0,824 & 2 & 53 & 4 & Signifikan \\
$\mathrm{X} 1 \rightarrow \mathrm{Z}$ & Linear & 0,192 & 12,835 & 1 & 54 & 0,00 & Tidak Signifikan \\
$\mathrm{X} 2 \rightarrow \mathrm{Z}$ & Logaritmic & 0,100 & 5,970 & 1 & 54 & 1 & Signifikan \\
$\mathrm{X} 3 \rightarrow \mathrm{Z}$ & S & 0,163 & 10,517 & 1 & 54 & 0,01 & Signifikan \\
$\mathrm{Y} \rightarrow \mathrm{Z}$ & Linear & 0,172 & 11,213 & 1 & 54 & 8 & Signifikan \\
& Linear & & & & & 0,00 & Signifikan \\
& & & & & & 0,00 & \\
& & & & & & 1 & \\
\hline
\end{tabular}

(Sumber: Data diolah, 2020)

Hasil uji linieritas pada masing-masing jalur (path) satuan linier.

menghasilkan keputusan untuk menggunakan

$\mathbf{U}$

\section{ji Hipotesis}

Uji hipotesis ditujukan untuk membuktikan secara ilmiah faktor-faktor yang mempengaruhi Profitabilitas dan implikasinya pada Corporate Value yang dilakukan dengan analisis jalur (path

$$
\begin{aligned}
& \mathrm{Y}=6,71-0,037 \mathrm{X} 1-0,112 \mathrm{X} 2-0,056 \mathrm{X} 3+\mathrm{e} 1 \\
& \mathrm{Z}=15,344-1,011 \mathrm{X} 1-0,589 \mathrm{X} 2-0,561 \mathrm{X} 3+2,364 \mathrm{Y}+\mathrm{e} 2
\end{aligned}
$$

Tabel 7. Rangkuman Hasil Uji Koefisien Determinasi Total $\left(\mathbf{R m}^{2}\right)$

\begin{tabular}{llcc}
\hline & \multicolumn{1}{l}{ Nilai R Nilai Adjusted R-Square } & $\begin{array}{c}\text { Std. Error of the } \\
\text { Estimate }\end{array}$ \\
\hline $\begin{array}{l}\text { Model Regresi } \\
1\end{array}$ & 0,382 & 0,097 & 0,3208649 \\
$\begin{array}{l}\text { Model Regresi } \\
2\end{array}$ & 0,632 & 0,353 & 2,4394325 \\
\hline
\end{tabular}

(Sumber: Data diolah, 2020)

Hasil Perhitungan Standar error of estimate dari Model Regresi I:

$$
\begin{aligned}
& =\frac{\operatorname{Pe} 1=\sqrt{1-\mathrm{R}^{2}}}{}=\sqrt{0,903} \\
& =0,9503
\end{aligned}
$$

Hasil Perhitungan Standar error of estimate dari Model Regresi II:

$$
\begin{array}{ll}
= & \multicolumn{1}{|c|}{\mathrm{Pe} 1=\sqrt{1-\mathrm{R}^{2}}} \\
= & \sqrt{1-(0,353)}=\sqrt{0,647} \\
= & 0,8044
\end{array}
$$

Berdasarkan total keragaman data pada model regresi di atas, dapat dihitung dengan rumus: 


$$
\begin{aligned}
& =1-(0,9503)^{2} \times(0,8044)^{2} \\
& =1-(0,9031 \times 0,6471) \\
& =1-0,5844 \\
& =0,4156
\end{aligned}
$$

Nilai koefisien determinasi total $\left(\mathrm{Rm}^{2}\right)$ menghasilkan skor 0,4156 , artinya 41,56 persen

\begin{tabular}{|c|c|c|c|c|}
\hline $\begin{array}{l}\text { Jalur } \\
\text { (Path) }\end{array}$ & $\begin{array}{c}\text { Hubungan } \\
\text { antar Variabel }\end{array}$ & $\begin{array}{c}\text { Nilai } \\
\text { Standardized } \\
\text { Beta }(\beta)\end{array}$ & $\begin{array}{l}\text { Probabilitas } \\
\text { Signifikansi }\end{array}$ & Hasil Pengujian \\
\hline p1 & $\mathrm{H}_{1}: \mathrm{X} 1 \rightarrow \mathrm{Y}$ & $-0,037$ & 0,474 & Tidak signifikan \\
\hline p2 & $\mathrm{H}_{2}: \mathrm{X} 2 \rightarrow \mathrm{Y}$ & $-0,112$ & 0,012 & Signifikan \\
\hline p3 & $\mathrm{H}_{3}: \mathrm{X} 3 \rightarrow \mathrm{Y}$ & $-0,056$ & 0,092 & Tidak signifikan \\
\hline $\mathrm{p} 4$ & $\mathrm{H}_{4}: \mathrm{Y} \rightarrow \mathrm{Z}$ & 2,364 & 0,029 & Signifikan \\
\hline
\end{tabular}
peubah atas variabel corporate value dapat diidentifikasi oleh variabel ukuran perusahaan, likuiditas, dan leverage dengan variabel

(Sumber: Data diolah, 2020)

Profitabilitas sebagai fungsi intervening sedangkan sisanya 58,44 persen diidentifikasi oleh faktor lain yang tidak diikutsertakan dalam model penelitian ini.
Uji hipotesis indirect effect dilakukan dengan teknik sobel test dengan Profitabilitas (Y) sebagai variabel intervening. Hasil uji direct effect $\mathrm{p} 1$ atas variabel Ukuran Perusahaan diketahui menghasilkan probabilitas signifikansi lebih besar

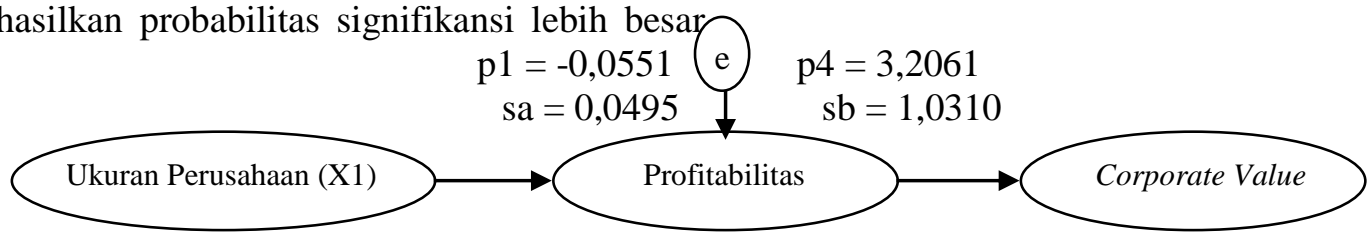

$\mathrm{z}$, sig. $=0,3164$

(Sumber: Output SPSS Ver23.00, 2020)

Gambar 4. Pengaruh indirect antar Variabel X1 dan Z

Hasil sobel test menghasilkan skor koefisien mediasi $-0,1765$ berada dengan probabilitas signifikansi sebesar 0,3164 (lebih besar dari 0,05).

$$
\begin{aligned}
\mathrm{t} & =\frac{-0,1765}{0,1762} \\
\mathrm{t} & =-1,002
\end{aligned}
$$

Nilai t hitung sebesar $-1,002$ menghasilkan skor yang lebih kecil $(<)$ dari $t$ tabel $(1,96)$ sehingga menolak H5. Variabel Profitabilitas tidak memediasi pengaruh Ukuran Perusahaan terhadap Corporate Value.

Uji hipotesis indirect effect dilakukan dengan teknik sobel test dengan dengan Profitabilitas (Y)

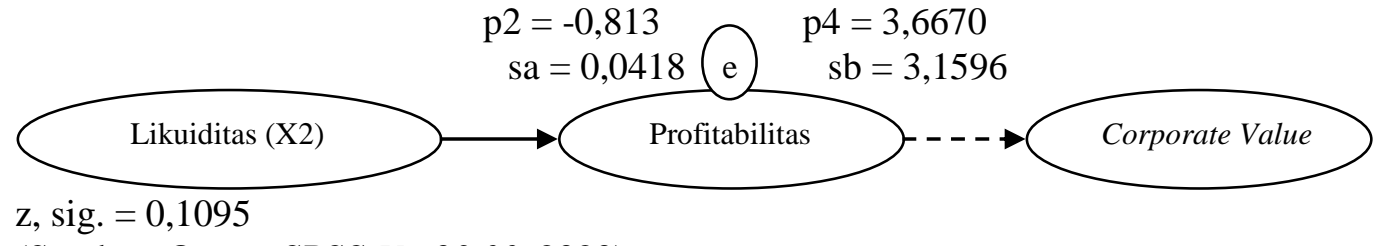

(Sumber: Output SPSS Ver23.00, 2020) dari (>) 0,05 (Tabel 8) sehingga menolak $\mathbf{H}_{1}$. Selanjutnya, output dari SPSS 23.00 hasil dari pengujian $\mathrm{p}_{1} \rightarrow \mathrm{p}_{4}$ melalui analisis jalur (path analysis) indirect effect yaitu:
Nilai standard error adalah 0,1762 sehingga nilai $t$ hitung menjadi: sebagai variabel intervening. Hasil uji direct effect p2 atas variabel Likuiditas diketahui menghasilkan probabilitas signifikansi lebih kecil dari $(<)$ 0,05 (Tabel 8) sehingga menerima $\mathbf{H}_{2}$. Selanjutnya, output dari SPSS 23.00 hasil dari pengujian $\mathrm{p}_{2} \rightarrow$ $\mathrm{p}_{4}$ melalui analisis jalur (path analysis) indirect effect yaitu: 
Hasil sobel test menghasilkan skor koefisien mediasi -0,2982 berada dengan probabilitas signifikansi sebesar 0,1095 (lebih besar dari 0,05).

$$
\begin{aligned}
\mathrm{t} & =\frac{-0,2982}{0,1863} \\
\mathrm{t} & =-1,6006
\end{aligned}
$$

Nilai t hitung sebesar $-1,6006$ menghasilkan skor yang lebih kecil $(<)$ dari t tabel $(1,96)$ sehingga menolak $\mathbf{H}_{6}$. Variabel Profitabilitas tidak memediasi pengaruh Likuiditas terhadap Corporate Value.

Uji hipotesis indirect effect dilakukan dengan teknik sobel test dengan Profitabilitas (Y) sebagai
Nilai standard error adalah 0,1863 sehingga nilai t hitung menjadi: variabel intervening. Hasil uji direct effect $\mathrm{p} 3$ atas variabel Leverage diketahui menghasilkan probabilitas signifikansi lebih besar dari (>) 0,812 (Tabel 8) sehingga menolak $\mathbf{H}_{3}$. Selanjutnya, output dari SPSS 23.00 hasil dari pengujian $\mathrm{p}_{3} \rightarrow$ $\mathrm{p}_{5}$ melalui analisis jalur (path analysis) indirect effect yaitu:

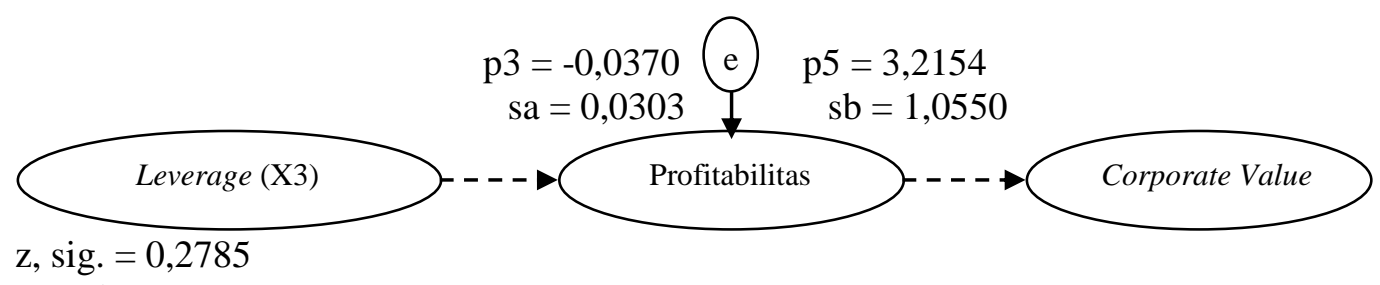

(Sumber: Output SPSS Ver23.00, 2020)

Gambar 6. Pengaruh indirect antar Variabel X3 dan Z

Hasil sobel test menghasilkan skor koefisien mediasi $-0,1190$ berada dengan probabilitas signifikansi sebesar 0,2785 (lebih besar dari 0,05).

$$
\begin{aligned}
\mathrm{t} & =\frac{-0,119}{0,1098} \\
\mathrm{t} & =-1,0838
\end{aligned}
$$

Nilai t hitung sebesar $-1,0838$ menghasilkan skor yang lebih kecil $(<)$ dari t tabel $(1,96)$ sehingga menolak $\mathbf{H}_{7}$. Variabel Profitabilitas tidak memediasi pengaruh Leverage terhadap Corporate Value.

\section{Pembahasan}

Hasil penelitian atas 7 (tujuh) hipotesis alternatif yang diusulkan, hanya 2 (dua) hipotesis terbukti berpengaruh secara signifikan yaitu $\mathbf{H}_{2}$, dan $\mathbf{H}_{4}$. Dengan kata lain, penelitian ini bertujuan untuk menganalisis dan membuktikan secara empiris faktor-faktor yang mempengaruhi Profitabilitas yang terdiri dari ukuran perusahaan, likuiditas, dan leverage serta melihat implikasinya pada Corporate Value (indirect effect) melalui Profitabilitas sebagai variabel intervening diuraikan sebagai berikut:

Hipotesis ke-1: nilai koefisien regresi untuk variabel ukuran perusahaan sebesar -0,037 dengan probabilitas signifikansi sebesar 0,747 sehingga menolak $\mathrm{H}_{1}$. Hipotesis ini secara statistik tidak membuktikan bahwa ukuran perusahaan memiliki
Nilai standard error adalah 0,1098 sehingga nilai t hitung menjadi:

Hasil uji direct effect $\mathrm{p} 4$ atas variabel Profitabilitas terhadap Corporate Value diketahui menghasilkan probabilitas signifikansi lebih kecil dari $(<)$ 0,05 (Tabel 8) sehingga menerima $\mathbf{H}_{4}$.

pengaruh signifikan terhadap Profitabilitas. Temuan penelitian ini tidak mengkonfirmasi temuan ukuran perusahaan yang signifikan berpengaruh atas faktor profitabilitas (Dwija Bhawa \& Dewi S., 2015). Besar kecilnya ukuran perusahaan pada perusahaan Sub Sektor Transportasi yang menjadi sampel dalam penelitian ini tidak menjadi faktor penentu dalam mengevaluasi profitabilitas perusahaan.

Hipotesis ke-2: nilai koefisien regresi untuk variabel likuiditas sebesar $-0,112$ dengan probabilitas signifikansi sebesar 0,012 sehingga menerima $\mathrm{H}_{2}$. Hipotesis ini secara statistik membuktikan bahwa likuiditas memiliki pengaruh negatif terhadap Profitabilitas. Temuan penelitian ini mengkonfirmasi temuan perputaran kas yang diproksikan sebagai likuiditas perusahaan yang 
signifikan berpengaruh atas faktor profitabilitas (Dwija Bhawa \& Dewi S., 2015; Priyanto, 2019). Semakin cepat likuiditas perusahaan melalui perputaran kas untuk menghasilkan laba ditunjukan dalam peningkatan profitabilitas perusahaan.

Hipotesis ke-3: nilai koefisien regresi untuk variabel leverage sebesar $-0,056$ dengan probabilitas signifikansi sebesar 0,092 sehingga menolak $\mathrm{H}_{3}$. Hipotesis ini secara statistik tidak membuktikan bahwa leverage memiliki pengaruh signifikan terhadap Profitabilitas. Temuan penelitian ini tidak mengkonfirmasi temuan leverage yang signifikan berpengaruh atas faktor profitabilitas (Wulandari \& Wiksuana, 2017). Besar kecilnya leverage pada perusahaan Sub Sektor Transportasi yang menjadi sampel dalam penelitian ini tidak menjadi faktor penentu dalam mengevaluasi profitabilitas perusahaan.

Hipotesis ke-4: nilai koefisien regresi untuk variabel profitabilitas sebesar 2,364 dengan probabilitas signifikansi sebesar 0,029 sehingga menerima $\mathrm{H}_{4}$. Hipotesis ini secara statistik membuktikan bahwa profitabilitas memiliki pengaruh signifikan terhadap Corporate Value. Temuan penelitian ini tidak mengkonfirmasi temuan profitabilitas yang berpengaruh tidak signifikan atas nilai perusahaan (Wulandari \& Wiksuana, 2017; Azmy \& Vitriyani, 2019). Besar kecilnya leverage pada perusahaan Sub Sektor Transportasi yang menjadi sampel dalam penelitian ini tidak menjadi faktor penentu dalam mengevaluasi profitabilitas perusahaan. Semakin tinggi profitabilitas yang dihasilkan pada penelitian ini mencerminkan sebagai bentuk evaluasi kinerja yang diukur berdasarkan imbas hasil aset artinya perusahaan mampu menutup investasi yang digunakan untuk membiayai investasinya dari dana yang berasal dari sumber internal yang tersedia dalam bentuk laba ditahan.

Hipotesis ke-5: nilai koefisien mediasi untuk variabel profitabilitas atas ukuran perusahaan

\section{SIMPULAN DAN SARAN}

\section{Simpulan}

Faktor-faktor yang mempengaruhi Profitabilitas yang terdiri dari Ukuran Perusahaan, Likuiditas dan Leverage, hanya dibuktikan melalui likuiditas berpengaruh negatif terhadap profitabilitas perusahaan sedangkan profitabilitas berpengaruh positif terhadap corporave value. Ukuran Perusahaan dan leverage tidak berpengaruh signifikan terhadap profitabilitas perusahaan. Keseluruhan faktor Ukuran Perusahaan, Likuiditas, dan Leverage pada penelitian ini tidak sebesar -0,1765 dengan probabilitas signifikansi-z sebesar 0,3164 sehingga menolak $\mathbf{H}_{5}$. Hipotesis ini secara statistik tidak membuktikan ukuran perusahaan mampu memediasi terhadap corporate value melalui peranan corporate social responsibility (Wulandari \& Wiksuana, 2017), hal ini dapat dipahami bahwa perusahaan Sub Sektor Transportasi yang menjadi sampel dalam penelitian ini berarti tidak menjadikan faktor ukuran perusahaan untuk mengevaluasi tingkat pengembalian aset perusahaan dalam rangka meningkatkan corporate value.

Hipotesis ke-6: nilai koefisien mediasi untuk variabel profitabilitas atas likuiditas sebesar 0,2982 dengan probabilitas signifikansi-z sebesar 0,1095 sehingga menolak $\mathbf{H}_{6}$. Hipotesis ini secara statistik tidak membuktikan likuiditas mampu memediasi terhadap corporate value melalui profitabilitas perusahaan, hal ini dapat dipahami bahwa perusahaan Sub Sektor Transportasi yang menjadi sampel dalam penelitian ini berarti tidak menjadikan faktor likuiditas untuk mengevaluasi tingkat pengembalian aset perusahaan dalam rangka meningkatkan corporate value.

Hipotesis ke-7: nilai koefisien mediasi untuk variabel profitabilitas atas likuiditas sebesar 1,0838 dengan probabilitas signifikansi-z sebesar 0,2795 sehingga menolak $\mathbf{H}_{7}$. Hipotesis ini secara statistik tidak membuktikan leverage mampu memediasi terhadap corporate value melalui peranan corporate social responsibility (Wulandari \& Wiksuana, 2017), sementara leverage yang diproksikan dengan DER secara langsung tidak berpengaruh signifikan terhadap nilai perusahaan (Azmy \& Vitriyani, 2019) hal ini dapat dipahami bahwa perusahaan Sub Sektor Transportasi yang menjadi sampel dalam penelitian ini berarti tidak menjadikan faktor leverage untuk mengevaluasi tingkat pengembalian aset perusahaan dalam rangka meningkatkan corporate value

Profitabilitas yang difungsikan sebagai variabel intervening.

\section{Saran}

Hasil penelitian ini dapat memberikan kontribusi dalam mengkaji kembali faktor-faktor lain yang belum sepenuhnya dapat membuktikan secara empiris terhadap Profitabilitas yang bertujuan mengevaluasi dampaknya pada Corporate Value. Penambahan faktor rasio keuangan lainnya sepertinya rasio aktivitas dan pangsa pasar dengan proksi inventory turnover, dividend payout 
pengukuran nilai perusahaan pendekatan price earnings ratio (PER), price book value ratio (PBVR), market book ratio (MBR) dapat dievaluasi kembali pada penelitian mendatang. Perluasan jumlah sampel juga

\section{DAFTAR PUSTAKA}

Azmy, A., \& Vitriyani. (2019). Pengaruh Rasio Kinerja Keuangan Terhadap Nilai Perusahaan BUMN Non-Keuangan Di Bursa Efek Indonesia. Fokus Bisnis: Media Pengkajian Manajemen dan Akuntansi, 18(2), 1-10.

Brigham, E. F., \& Houston, J. F. (2014). Dasar-Dasar Manajemen Keuangan. Jakarta: Salemba Empat.

Dwija Bhawa, I. B., \& Dewi S., M. R. (2015). Pengaruh Ukuran Perusahaan, Likuiditas, Profitabilitas, Dan Risiko Bisnis Terhadap Struktur Modal Perusahaan Farmasi. E-Jurnal Manajemen Unud, 4(7), 1949-1966.

Elim, J. (2019). Model of Firm Value - Indonesian Stock Exchange Case. International Journal of Economics and Financial Issues, 9(3), 154162.

Elinda, F., \& Sukirman. (2015). Determinan Rasio Keuangan Terhadap Kebijakan Dividen. Accounting Analysis Journal, 4(4), 1-8.

Haryanto, \& Aprilia, L. (2008). Asosiasi antara Karakteristik Perusahaan dan Kualitas Pengungkapan Sukarela dalam Laporan Tahunan. Retrieved Desember 2018, from eprints UNDIP: https://core.ac.uk/download/pdf/11737417.pdf

Heder, \& Priyadi, M. P. (2017). Pengaruh Kinerja Keuangan terhadap Nilai Perusahaan dengan Good Corporate Governance sebagai Variabel Pemoderasi. Jurnal Ilmu dan Riset Akuntansi, 6(7), 1-17.

Horne, J. C., \& Wachowicz Jr., J. M. (2012). Prinsip-prinsip Manajemen Keuangan (Buku 1) (13 ed.). (Q. Mubarakah, Trans.) Jakarta: Salemba Empat.

Husain, T. (2019). An Analysis of Modeling Audit Quality Measurement Based on Decision Support Systems (DSS). European Journal of Scientific Exploration, 2(6), 1-9.

Husain, T., Sarwani, Sunardi, N., \& Lisdawati. (2020). Firm's Value Prediction Based on Profitability Ratios and Dividend Policy. Finance \& Economics Review, 2(2), 13-26.

IAI. (2013). Pernyataan Standar Akuntansi Keuangan. Jakarta: Dewan Standar Akuntansi Keuangan - Ikatan Akuntan Indonesia. perlu dilakukan mengingat pada penelitian ini hanya melibatkan perusahaan pada Sub Sektor Transportasi yang terdaftar di Bursa Efek Indonesia (BEI).

Kasmir, D. (2016). Analisis Laporan Keuangan. Jakarta: PT. Rajagrafindo Persada.

Kementerian Perhubungan Republik Indonesia. (2015, Agustus 28). Jelang MEA 2016, Kemenhub Minta Operator Transportasi Tingkatkan Profesionalitas Manajerial. Retrieved Desember 2018, from dephub.go.id: http://www.dephub.go.id/berita/baca/jelangmea-2016,-kemenhub-minta-operatortransportasi-tingkatkan-profesionalitasmanajerial/?cat=QmVyaXRhfHNlY3Rpb24tNj $\mathrm{U}=$

Kementerian PPN/ Bappenas. (n.d.). Bab 33: Percepatan Pembangunan Infrastruktur. Retrieved Desember 2018, from Bappenas: https://www.bappenas.go.id/files/7013/5027/45 14/bab-33_20091007094529_2158_34.pdf

Kieso, D. E., Weygandt, J. J., \& Kimmel, P. D. (2013). Accounting Principle (11 ed.). London : John Wiley \& Sons Inc.

Priyanto, A. A. (2019). Faktor-Faktor yang Mempengaruhi Return On Assets (ROA). Jurnal Ilmu Manajemen, 9(1), 64-75.

Restanti, R. W., \& Husain, T. (2018). Pengaruh Karakteristik Perusahaan Terhadap Corporate Social Responsibility Disclosure. MABISKA Journal, $3(1), 48-62$.

Rudianto, D. (2015). Comparison of Financial Performance and Stock Price Before and After Ex-Dividend Listed Companies in Indoensia Stock Exchange. The International Journal of Economic and Social Research, 11(11), 185195.

Subramanyam, K. R. (2014). Financial Statement Analysis (11th / International ed.). New York: McGrawHill.

Sugiyono. (2018). Metode Penelitian Evaluasi: Pendekatan Kuantitatif, Kualitatif, dan Kombinasi. Bandung: CV. Alfabeta.

Titman, S., Keown, A. J., \& Martin, J. D. (2018). Financial Management: Principles and Applications. Boston: Prentice Hall.

Trisna Dewi, I. A., \& Sujana, I. K. (2019). Pengaruh Likuiditas, Pertumbuhan Penjualan, dan Risiko Bisnis terhadap Nilai Perusahaan. E-Jurnal Akuntansi Universitas Udayana, 26(1), 85-110. 
Widhiasthini, N. W., \& Subawa, N. S. (2019). Sisi Lain Praktek Transportasi Online Sebagai Transformasi Ekonomi Politik Di Era Revolusi Industri 4.0. Public Administration Journal, 1(4), 202-215.

Wulandari, N. M., \& Wiksuana, I. G. (2017). Peranan Corporate Social Responsibility dalam Memoderasi Pengaruh Profitabilitas, Leverage dan Ukuran Perusahaan Terhadap Nilai Perusahaan. E-Jurnal Manajemen Unud, 6(3), 1278-1311.
Yanti. (2018). Analisa Pengaruh Faktor-Faktor Pembentuk Fee Ijarah (PSAK 107) Terhadap Portofolio Rahn Emas Di Bank Syariah. Jurnal Buana Akuntansi, 3(1), 24-55. 